資 料

\title{
理科の概念学習における概念地図完成法の効果に関する研究
}

\author{
皆川順 ${ }^{1}$
}

ON THE EFFECT OF MAP-COMPLETION WORK ON CONCEPT LEARNING IN SCIENCE

Jun Minagawa

In Novak's "concept mapping", fully constructed "concept map" is shown to subjects before and/or after mapping work. As it takes too much time to get satisfactory results, in this study map completion tasks were introduced. Subjects were to insert some of the suitable concepts or lines into the blanks to make up the map wholly. In preliminary experiments the difficulty of getting satisfactory results were tested. In Exp. I , map completion task with some blanks of concepts are found to be the most effctive. In Exp. II, time spent on this task were manipulated. Subjects had negative effects when only 5 minutes were allowed. When 25 minutes were spent on this task in a 50 minute-experiment, subjects had the best positive effects.

Key words : concept mapping, map completion task.

これまで理科教育界においては,「基本的科学概念と は何か」についての討議が繰り返しなされてきた。し かし，一方では，広瀬 (1992) の言う「教科を学習する ということは, 多くの知識を整理し，大切な基本的概 念をべースにして，どのようにそれらの概念と概念と が関係づけられているかを学習することである」とい うことについては，ほとんど議論の対象にならなかっ た。

家野(1992)によれば, 科学哲学者, 例えば, Hempel, C.G. (1967) は, 科学概念や法則・原理の持つ構造性と 概念の重要性の問題を論じている。

よく体制化された記憶は安定した情報をもたらすと ともに，処理・検索が容易になることが知られている がそれは，体制化によって項目数が減少するからであ ると言われている。Gagné, E.D. (1985) は，長期記憶に 関して体制化されている子供とそうでない子供とを比 較し，作動記憶の容量との関連で説明を行っている。 体制化のためにグラフを用いる方略は以前からあり，

1 筑波大学心理学研究科 (Doctoral Program in Psychology, University of Tsukuba)
辰野 (1992) は諸研究を紹介しつつ「学習者自身が鍵概 念の間に相互関係を構成するように努めることが必要 である」と述べている。

Glynn, S.M. \& Di Vesta (1977) は, 階層的な分類 概要を与えることによって, 再生成績が向上する事を 見いだした。

上記のような, 完成されたグラフや説明を事前に与 える方略に対し, 概念間の関係を被験者に描かせる教 授法がある。

Novak, J.D. \& Gowin, D.B. (1984) は，概念及びそ れをつなぐ命題を重視し，これらの関係をグラフとし て描かせることによって，知識表象の外化を試み，こ れを概念地図 (concept map) と名づけた。

概念地図は Heinze-Fry, J.A. \& Novak, J.D. (1990) によれば「当初, 学習者の先行知識とその知識間の相 互関係を研究するための手段として発展してきたが, その後, 学習者の有意味学習を促進する手段として発 展した」という。ちなみにこの方法は「概念地図作成 法」(concept mapping) と名づけられた。

Novak, J.D.らは，学習者の年齢や学年にあわせて 様々な学習方法を提示しているが, 一般的には学習者 
自身が教科書から概念を選び出し，それら相互の間の 関係を考えながら，学習者自身が概念間をリンクで結 び，関係を意味する結合語 (linking words)をリンク上 に書くことで, 概念地図は完成する。教師は, 概念地 四作成のための援助や指導をするが, 作成後, 個人面 接によって教師が作成した概念地図と照合し，教師は 学習者の概念地図の詋りを訂正する。

この「詋りを正す」という行為は, 教師ないし実験 者の側に「正しい概念地図」という考えがあるからこ そ可能であると言える。Novak, J.D.らは,この方法は 従来の記憶中心学習に対して有意味学習であるとして, 概念地図を作成することによって, 学習者はそれまで 混沌としていた未整理の, ないしは意識化されていな かった概念間の関係に気づくとし，この方法の教育的 意義を強調している。

他方, 概念地図作成法及び類似した方法による研究 としては以下のものがある。

Champagne, A.B., Klopfer, L.E., Dresna, A.T. \& Squires, D.A. (1981) の例では, 概念構造化分析法 (Con SAT : concept structuring analysis) を用いている。この 方法は, 概念, リンク, リンクラベルを構成し, 授業 前後に行って知識構造の変化を調べる点はNovakら の概念地図作成法と共通しているが他方, 概念構造の 構成にあたっては「下位の概念から上位の概念へ」作 成指導を行っている。

Okebukola, P.A. (1990) は, 遺伝学と生態学との教 授に関して, 概念地図作成法と通常の授業とを比較・ 研究している。評価には 4 肢選択法が用いられた。

Stensvold, M.S. \& Wilson, J.T. (1990) は, 化学実 験における研究で, 言語能力と概念地図作成法の効果 との間に交互作用を見いだしている。

わが国では, 福岡・笠井 (1991), 福岡・植田 (1991)

の, 学校授業場面での実験的研究がある。

ところで, 先行オーガナイザーは, Ausubel, D.P. (1968) の提唱したものであり, 後続の学習内容と関連 を持ちつつ，それを包捸するより一般的・抽象的な内 容であり,それによって後続の知識が精緻化されるも のである。それゆえ, 概念地図作成法とは異なるが, Novak ら（1984）は自らの理論的基盤が, Ausubel, D. P.の理論にあると主張している。

Novak ら (1984)は, 概念地図は階層的構造をなして いると考え, 地図の得点化については(1)関係性（Relationships) (2)階層性 (Hierarchy) (3)横断結合 (Cross links) (4)例 (Examples) の各々に, 得点を与える方法を提唱し ている。ここで横断結合とは, 概念地図に於けるセグ
メント間の有意味な結合であり，それは「創造的能力 を示して」おり，また「関連はしているが明確に異な る領域間での統合的再調整の証拠」(Novak, J.D. ; 1985) である。実際, 横断結合には高い得点が与えられてい る。

しかし, Novakらは, それぞれの簓所に, 何ゆえに それらの得点が与えられるのか, 明確な根拠を示して いない。

他方, これまでのところ, 横断結合をも含めた種々 の, 2 つの概念間の関係に的を絞り, それを意戝的に 考えさせた研究は見当たらない。

また Novak ら（1984）によれば，この方法による効 果が通常の授業の効果を上回るには 6 ～ 8 週間を要す ると述べているが，わが国の学校 (特に中学・高校) に於 いてはそのようなゆとりを得ることは極めて困難であ り，実施可能性に問題がある。

このように, 先行研究を概括すると, 長期にわたる 実験授業に於いては概念地図作成法は効果的である事 を示しているが, 他方, 効果発現までにあまりにも時 間がかかり, かつ, 概念地図そのものの得点化につい ても難点があると言えよう。

さて被験者に地州を独自で作成させるという, 本来 の概念地図作成法によって, 新奇な材料を被験者自身 の力で体制化できるょうになることは十分期待できる であろう。

しかし, 単元を学習するということは, 個々の概念 を各自の認知構造の中に定位させることであり，その 際概念同士のつながりが重要であるから, 構造を示す 地図を全体的に作成させるのみならず，さまざまな概 念間の関係把握の指導を行うことも必要であろう。

本研究は, この点に着目したものである。この目的 のために, 被験者の既有の認知構造の違いを直接問題 とせずに, 実験者作成の未完成の概念地図を与え, そ れを完成させることによって, 意図的に概念間の関係 を考えさせるという方略を用いた。これは, 被験者が 関係が深いと考える概念間のみならず，それ以外の概 念間の関係把握をも訓練させることによって, 同様な 教材に対する教え方の, 学年上昇に伴う変化にも柔軟 に対処できるようにさせることを目的としたものであ る。そのため, 事前一事後テスト課題は, さまざまな 概念間の関係を問う形式とした。

そこで，概念間の関係をより広く把握させるための 訓練を行った。それによって, 例えば「自然界の物質 の循環」という単元をまとめるとき, 動物の排泄物 $\rightarrow$ 第 2 次消費者という 2 つ概念の関係を考えるに際し 
て，これらの概念が，分解者（菌類・細菌類）による分 解, 窒素化合物, 生産者（緑色植物）の根からの吸収, 植物体内でのタンパク質の合成，第 1 次消費者(草食動 物) ・・・という連鎖を考えることによって説明可能で あることを知り得る。

Novak ら (1984)の方法は, ともすれば直接結びつく 概念・隣接する概念・直接の上位または下位概念といつ た「まとめ易い概念同士の結びつき，あるいはそれ らの発見を促す指導に力点がおかれていたのではある まいか。他方筆者は，横断結合の考えから示唆を受け， 基本的には単元内のあらゆる概念同士が結びつくこと が可能であると想定し，その結びつき方を考えさせる ことを目指した。

この目的のために先行の諸研究を再検討し, 最も重 要なのは概念の理解と概念間の関係の把握と考えて, 実験的研究を企画した。実験者側であらかじめ概念地 図を部分的に作成して被験者に提示し，それを完成さ せる (独立变数) ことによって, 従来の研究に比較して, より多くの概念間の関係を把握させる(従属变数) とい うものである。従って本研究の目的は, 未完成の概念 地図を被験者に完成させることが，諸概念間の関係を 把握できるようになり得るかを実験的に検討する事で ある。その際に, 限定された時間の中で, 最も効果的 な作業時間・課題の割合についても検討する。

そこで以下の実験を行った。実験 I, II における作 業課題は FIGURE 1-1, 事前テス卜・事後テス卜課題は FIGURE 1-2 のとおりである。

\section{予備実 験}

\section{目 的}

先行研究の結果及び Novak, J.D.等の主張を再検討 し，わが国の学校教育への適用を視野にいれつつ，い ずれの群が何ゆえにテスト成績において優れるのかに ついて検討する。Novak, J.D. \& Gowin, D.B. (1984) は次のように主張する。すなわち,「概念地図作成法の ような有意味な学習方法が効果をあげるためには， 6 〜8 週間の期間が必要である。それまでは, 従来の方 法の方が, 学習効果が優れている。」

このことから，次の仮説を設定する。

\section{仮 説}

全体で50分間の概念地図完全作成実験を行う実験群 よりも, 説明文を読み, 完成された概念地図を見て学 習する無作図群のほうが，概念間の関係に関するテス ト成績が優れるであろう。

\begin{tabular}{|c|c|c|c|}
\hline 花のつくりと種子のできかた & ( & )学校( & ) 年( \\
\hline
\end{tabular}

次の文をじっくり読んでください。読み終わったら,下の図に進 みなさい。なお，文は何回読みなおしてもかまいません。

アブラナ等の花では中心にめしべがあり，それを囲むように， おしべ, 花びら，がくが順についている。めしべの先を柱頭とい い, その下の部分在花柱（かちゅう）という。さらにその下の根 元のふくらんだ部分を子房（しほう）という。また，おしべの先 には小さなふくろがあり，これをやくという。このやくの中に花 粉が入っている。おしべの根元から花粉までのあいだは花系 (か し)という。

めしべの子房の中には，胚珠（はいしゅ）とよばれる部分があ り，これがやがてできる種子のもとになる。

めしべのやくからでた花粉が，めしべの柱頭につくと，やがて 子房は成長して果実になり, 中の肧珠が種子になる。種子は果実 に包まれており，例えば力キの種子では肧（はい）と胚乳（はい にゅう)とに分かれている。肧は，種子をまいたときにできる若 い植物体のからだのもとになるものであり，肧乳はそのときの栄 養分になる。また, 種子全体は, 種皮（しゅひ）という皮におお われている。

次に，上の文を読みながら，先に行つた問題を思いだし，言葉 と言葉との関係をそれぞれ十分に考えながら，下の間の口のなか にあてはまる言葉を記入しなさい。

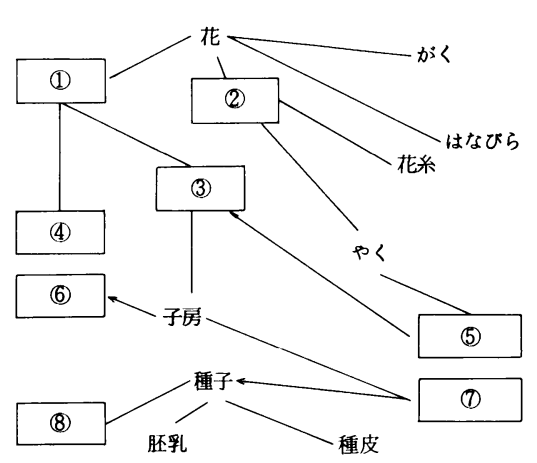

(1) $(\quad)$

(2) $(\quad)$

(3) $($ )

(4) $($ )

(5) $(\quad)$

(6) $(\quad)$

(7) $($ )

(8) $(\quad)$

FIGURE 1-1 概念地図作成課題の例：部分完成法 (課題 : 花のつくりと種子のでき方)

\section{方 法}

実験計画 1 要因 2 水準の被験者間計画。共分散分 析法による。統制変数, 基準変数はそれぞれ, 事前テ スト得点, 事後テスト得点である。

なお，テスト結果は共分散分析法を用いて処理し， 結果を調整平均で表示した。ここで共分散分析法に於 ける調整平均とは, 統制変数を調節し同質としたとき の基準変数の級平均である。以後, 実験処理に関して は，同様である。

実験年月 1993年 6 月上旬。 


\begin{tabular}{|c|c|c|c|}
\hline \multirow[t]{2}{*}{ 花についての調査 } & & ）学校（）年（ & \\
\hline & No. ( & ） 氏名（ & ) \\
\hline \multicolumn{4}{|c|}{$\begin{array}{l}\text { ＊この調査は学校の成績に関係ありません。楽な気持ちで受けて } \\
\text { ください。 }\end{array}$} \\
\hline \multicolumn{4}{|c|}{ 次の 2 つの志葉の間の関係について, 例にならつて簡単に説明 } \\
\hline \multicolumn{4}{|c|}{$\begin{array}{c}\text { (例)・鉛筆一ペン（どちらも，字を書くときの道具です） } \\
\text { ・服一冬 (冬は寒いので, 厚い服を着ます) }\end{array}$} \\
\hline 1. おしべ一やく & ) & 2. 花粉一柱頭（ & ) \\
\hline 3.めしべ一花柱 & ) & 4. めしべ一柱頭（ & ) \\
\hline $\begin{array}{l}\text { 5. 子房一胚珠（ } \\
\text { (以下略。全15問） }\end{array}$ & ) & 6. 子房一果実（ & ) \\
\hline \multicolumn{4}{|c|}{$\begin{array}{l}\text { ※実際のテスト問題用紙では, } \\
\text { 分に広い。 }\end{array}$} \\
\hline Figure $1-2$ & 事前テスト & ，事後テストの & 耦題 : \\
\hline
\end{tabular}

被験者 $\mathrm{K}$ 塾中学 2 年生 男子16名, 女子 16 名, 計 32 名。実験群は男子 7 名, 女子 9 名。無作図群は男女 とも 8 名。 2 群は，K塾作成の教科別実力テスト(1993 年 5 月下旬実施)で, ほぼ等しい得点をとつたため再設定 された2つのクラスであり, 塾の方針でU市の北部地 区・南部地区の学校別に分けられていた。

材料 $\mathrm{K}$ 塾教材「中学校 2 年理科精選問題集」の「血 液の循環」の単元（当時, 被験者生徒全員, 学校・塾では未学 習), 事前テスト及び事後テスト用紙, 概念地図作成用 紙 (実験群のみ)。

\section{手 続}

・時間配分 事前テスト 10分, 授業（実験群は, 概念地 図作成を含む）25分。干涉課題 5 分。事後テスト 10 分。 合計50分。

- 授業材料の使い方 授業の資料は実験群・無作図群 双方の生徒に, 問題集の該当するページ(重要点のまとめ の部分）をコピーして与える。

・実験方法と教示「今日はこれから, 血液の循環につ いて勉強します。まず，みんながどれくらいよく知っ ているか,テストします。問題は15問です。時間は10 分です。最初に出席番号と名前とを書いてください。 はじめ，と言ったら問題をよく読んで答えて下さい。 やめ，と言ったら鉛筆をおいてください。それでは， はじめ。」10分経過後, やめさせて, 答案を回収する。 次に,「これから, 今日勉強する内容のプリントを配り ます。」実験群の授業のときには, 同時に概念地図作成 用紙も配布する。次に, 血液の循環について, 説明を 行うが, 実験群の授業では, 内容を適宜区切って, そ
の部分に関する概念地図作成を実施, 無作図群の授業 では,そのまま説明を続ける。

25分経過後, 授業をやめ, 干渉課題 (理科 2 分野「コケ類 とシダ植物」)を配布する。「今からこの問題を，5分間で 解きなさい。」と教示, 5 分後, 回収する。最後に事後 テストを制限時間10分であることを告げて行い，時間 経過後回収する。

\section{結 果}

・採点基準 文章完成法であるので，「血液の循環」の 原理に従った模範解答どおりに，各問 1 点で採点した。 字の間違いは, 筆者が判読できる限り正解とした。漢 字で書くべき所を平仮名にした場合も正解とした。

- 評定の信頼性 $K$ 塾の専任理科教師（元高等学校理科 教師)に, 独立に採点を依頼したところ, 全被験者の全 答案のうち 1 名に 2 簓所, 4 名に各 1 箇所, 計 6 箇所 筆者の解答と異なるところがあった。すべて答案の字 の間違いの程度の問題であった。評定者間の相関は $\mathrm{r}=.975, \mathrm{p}<.01$ であり, 評定の信頼性は高いと言える。 なお評定者間相関は，事前テスト及び事後テストの結 果をこみにして行ったが，これは一般に2つのテスト の相関が高いことが明らかになったからである。また 相関が高い場合，すべて筆者自身の結果をそのまま用 いた。

・共分散分析において, 事前テスト, 事後テストの双 方に，バートレットの分散の等質性の検定を行ったと ころ，いずれも分散は等質であった。また，級内回帰 も等質であった。結果は, $\mathrm{p}\langle .01$ で, 無作図群〉実験群 となった (FIGURE 2)。なお, 実験群の生徒のうち 7 名 は, 実験後の成績が実験前より低下した。

\section{考 察}

結果は全体的には Novak, J.D.の)主張通り(「十分な時 間をかけない間は, 従来の教授法の方が優れる」）となったが, 原因については考える余地がある。北尾（1991）による と, 一般に目的をきびしく意識すると, そこへ到達し ようとするために心的努力のほとんどが使われ, 問題 そのものを詳細に吟味したり，柔軟に考えを巡らすこ とができなくなることがある。この実験場面では，未 習の内容を不慣れな方略で学ぶ事を強いられた。実験 群の生徒は, 概念の意味の把握及び記憶の定着が不十 分なうちに概念地図を作成しようとすることによって, 概念間の関係把握が十分にできず，またその結果とし て生じた失敗経験との双方の影響により，事前と同一 のテスト課題を解答困難にしたと考えられる。そのこ とは, 実験群の生徒の約半数が, 実験後に成績が低下 したことからも推測できる。他方無作図群については, 


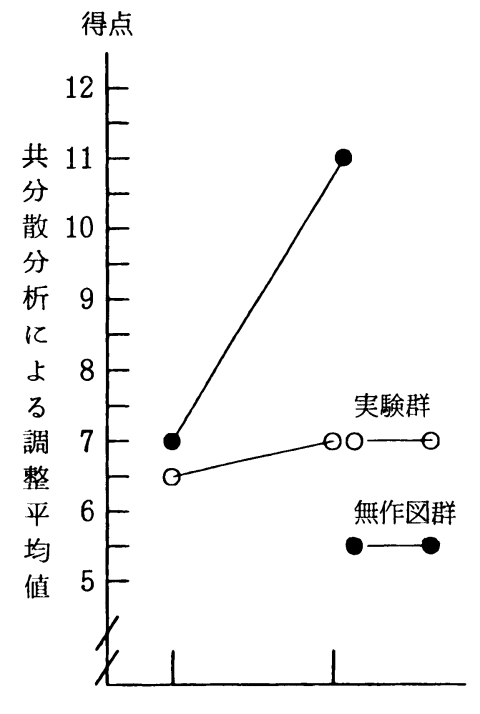

事前テスト 事後テスト

FIGURE 2 「血液の循環」課題

事前テストとして与えられた諸概念が，解説文に先行 提示して示される要約の役割を果たし, 解説文の理解 を促進し，事後テストの成績を向上させたと考えられ る。同様の効果は, 実験群では上述の理由で打ち消さ れたのであろう。

そこで実験群の設定に当たっては, 過度の緊張を与 えないよう配慮しつつ，いくつかの概念間の関係を自 ら判断させる方法が考えられる。この目的のためにま ず概念地図の部分完成課題を数種作成し, その効果を 比較検討することにした。この部分完成課題は, 被験 者に概念間の関係を意図的に考えさせるという点にお いて，通常の概念地図作成法よりも働きかけはより積 極的であると言える。

\section{実 験 I}

\section{目 的}

本実験の目的は，概念及び概念間の関係を部分的に 提示したとき，それを完成する行為が被験者の認知構 造に影響を与えるという仮定の下に, 部分提示の方法 を統制することによって被験者の完成行動を操作し, 概念間の関係を叙述させる形式で作成された事前テス 卜及び事後テストを変数としてその効果を検証し, 限 定された時間の中で最も効果的な概念把握の方法を見 いだすことである。

\section{方 法}

基本方針は以下の通りである。

(1)中学校の授業 1 時限 (50 分) 内に作業が終了するよう にする。

(2)被験者は, 実験者が部分的に作成したものを完成さ せる。

(3)概念地図の作成法は, 実験群にのみ, 文章の中で教 示する。

(4)概念間の関係理解（従属変数）に関して, 最も効果的 な方法を見いだすため,「概念」,「リンク」,「概念十リ ンク」を部分完成させ (独立变数), 効果量を比較して最 良の方法を採用する。

なお 3 つの実験は質的に異なるため, 課題数及び困 難度は統制困難である。特に, リンクの数はそれ自身 を統制しても連結し得る数は多く, 結果的に課題数 困難度とも概念のみ記入する場合と等質には出来得な い。しかしこの実験の性質から考えて, 課題数が多い ことにより作業がより一層困難になるとは必ずしも言 えない。限定された時間内での研究であることを考慮 し, 作業時間を統制し, 定められた時間内での効果量 で比較した。

(5)テストは実験前後に, 基本的には概念間の関係を記 入させる形で同一問題で行う (従属変数)。

(6)干涉課題もまた理科の教材から選び作成する。

また中学校で行った実験は, 群分けについては学級 をそのまま用いた。第 2 学年で実験を行った理由は, 各学校とも第 1 学年修了後, 学力的に等質な学級編成 を行っていることがあらかじめ確認されたからである。 実験 I -1 (概念記入による部分完成法の効果の検討)

実験計画 1 要因 3 水準の被験者間計画。共分散分 析法による。統制変数・基準変数はそれぞれ, 事前テ スト得点, 事後テスト得点である。

実験年月 1993年 7 月中旬。

被験者 U市立A 中学校第 2 学年生徒 男子54名, 女子51名, 計105名。 3 学級を 3 群に振り分けた。

材料 中学校理科 2 分野上「花のつくりと種子ので きかた」単元から構成した文章と，その下に未完成の 概念地図とを書き込んだ用紙。概念の数は, 完全に記 入された状態で17個。実験群 1 には空白 5 個, 実験群 2 には空白 8 個が有り，そこに，被験者に概念を記入 させ概念地図を完成させる。無作図群には概念地図の 部分を完成させた状態で与える。空白の位置に関して 実験群 1,2 ともに 3 バージョンをつくり, ランダム に配布した。他に，事前テスト及び事後テスト用紙。 干涉課題用紙。 


\section{手 続}

・時間配分 事前テスト10分，作業（実験群は，文章を読 み, 概念地図の空白を完成させる。無作図群は, 文章と完成した概 念地図とをよくみておく) 25 分, 干涉課題 5 分。事後テス 卜10分。計50分。

・実験方法と教示「今日はこれから,花の作りと種子 のでき方について復習します。まず，みんながどれく らいよく知っているか, テストします。問題は15問で す。時間は 10 分です。最初に出席番号と名前とを書い てください。

はじめ，と言ったら問題をよく読んで答えて下さい。 やめ, と言ったら鉛筆をおいてください。それでは, はじめ」10分経過後, やめさせて, 答案を回収する。 次に実験群, 無作図群の生徒に, それぞれ作業課題の 用紙を配布し，25分間作業するよう教示する。

25 分経過後, 作業をやめさせ, 干涉課題（理科 2 分野 「コケ類とシダ植物」）を配布， 5 分間で行うよう教示し， 5 分経過後, 回収する。最後に事後テストを配布し, 10分間で行うよう教示し，10分経過後，回収する。

実験 I ー 2 (リンク記入による部分完成法の効果の検討)

実験計画 1 要因 3 水準の被験者間計画。共分散分 析法による。統制変数・基準変数はそれぞれ, 事前テ スト得点，事後テスト得点である。

実験年月 1993 年 7 月中旬。

被験者 U市立B中学校 2 学年男子 54 名, 女子 49 名, 計103名。3 学級を 3 群に振り分けた。

材料 実験 I -1 と同じ用紙に, リンクのみ未完成 の概念地図を完成させる。記入すべきリンクの数は, 実験群 1 で 5 本, 実験群 2 で 8 本。実験 I -1 と同様, 3 バージョン作成しランダム配布。他は，実験 I - 1 と同じ。

手続 時間配分・実験方法と教示など，実験 I -1 と同じ。

実験 I ー3（概念及びリンク記入による部分完成法の効果）

実験計画 1 要因 3 水準の被験者間計画。共分散分 析法による。統制変数・基準変数はそれぞれ，事前テ スト得点，事後テスト得点である。

実験年月 1993 年 7 月中旬。

被験者 U市立C中学校第 2 学年生徒。男子51名, 女子50名, 計101名。 3 学級を 3 群に振り分けた。

材料 概念及びリンク共に未完成の概念地図を完成 させる。課題数は実験群 1 で概念 2 個+リンク 3 本, 実験群 2 で概念 4 個+リンク 4 本。各々 3 バージョン 作成し, ランダムに配布した。そのほかは, 実験 I - 2 と同じ。
手続 時間配分・実験方法と教示など，実験 I -1 と同じ。

\section{結 果}

・採点基準 被験者全員，中学 1 年の時に既習である ので,

(1)中学 1 年以上で学習する形式・内容の答えであるこ と(例えば, 小学校 5 年でも学んでいるが, その際は「肧珠」概念 が抜け落ち, 受粉の結果, 種と実が出来るよう, 記述されている。 また，中学校 1 年では学ばない「脽花」「雄花」の区別がある。こ れらに基づく答えは誤答とした

(2)概念そのものだけの記述ではなく，概念間の関係の 記述であること。その際，(1)概念地図上をたどった説 明 (2)理科 (生物学) で一般的に承認されている関係記 述のしかた (3)被験者 (生徒) を教えている理科教師が 教えた関係記述のしかた，は，いずれも正答とした。 また，これらが矛盾するときは，他の理科教師に意見 を求めた。

- 評定の信頼性 各被験校の生徒を教えている理科教 師 1 名と, 筆者とが独立に採点してその相関係数を求 めたところ, 実験 $\mathrm{I}-1$ については $\mathrm{r}=.820, \mathrm{p}<.01 て ゙$ 有意, 実験 $\mathrm{I}-2$ については $\mathrm{r}=.804, \mathrm{p}<.01$ で有意,

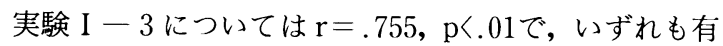
意であった。評定の信頼性は高いといえる。

共分散分析を行ったところ, 実験 I-1に扔いては 群間に有意差が見いだされた $(\mathrm{F}(2,101)=6.835, \quad \mathrm{p}<.01)$ 。 Tukey 法による多重比較の結果, 実験群 $2>$ 実験群 $1>$ 無作図群となった。

実験 I-2 p >.10で, 群間に有意差は見いだせな かった。

実験 $\mathrm{I}-3 \quad \mathrm{p}>$.10で，群間に有意差は見いだせな かった (FIGURE 3)。

\section{考 察}

本実験は制約された時間の中で, 最も効果的な方法 を探ることを枋らった。

この 3 つの実験は，概念間の関係を考える上で，(1) 関係 (リンク) を先行提示し, そこに概念を記入する課 題，(2)概念を先行提示し，それらの関係をリンクで結 ばせる課題，(3)概念及びリンクをともに部分的に先行 提示し, 地図を完成する課題，のうちいずれが概念間 の関係把握により効果的であるかを, 定められた作業 時間との関連で見いだそうとしたものである。

本研究における無作図群には作業課題は無い。それ ゆえ，実験結果からは少なくとも実験群 2 までの作業 


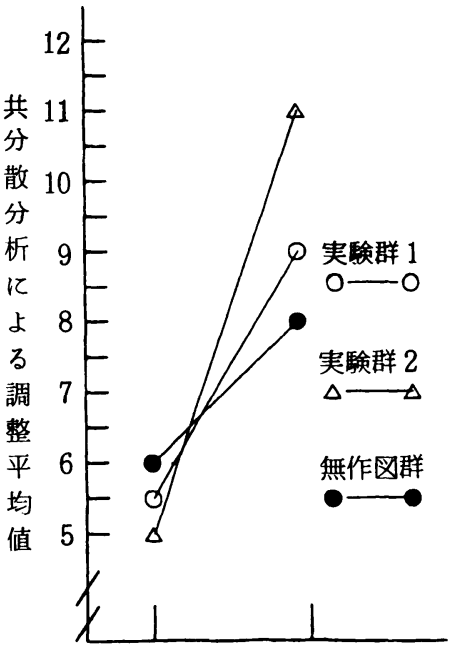

事前テスト 事後テスト

概念記入課題

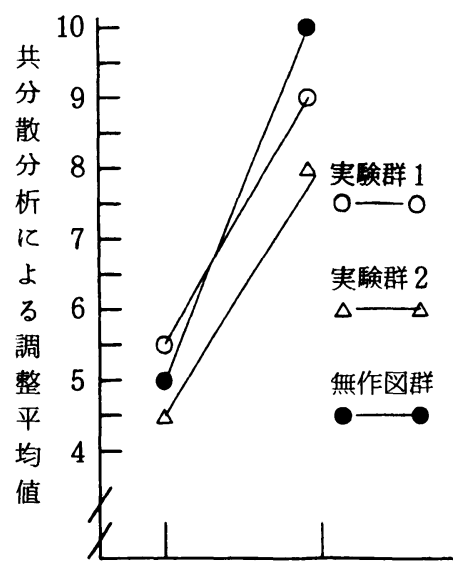

事前テスト 事後テスト リンク記入課題

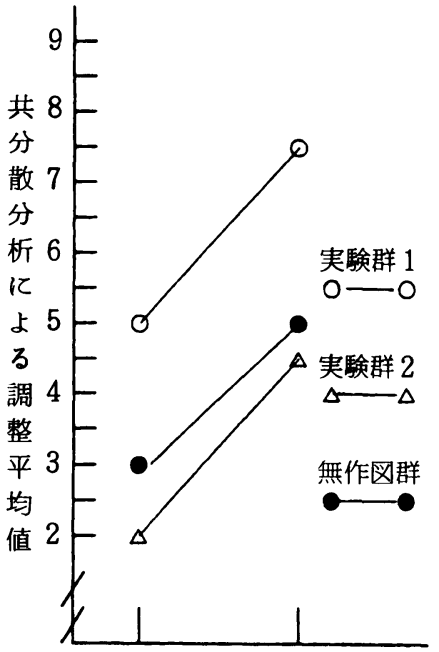

事前テスト 事後テスト

「概念十リンク」記入課題

FIGURE 3 記入課題別成績

課題数に関しては, 課題数の増加に伴って, テスト成 績は向上していることになる。

3 つの実験は質的に異なるが, 共通しているのは「概 念間の関係について考える」ことである。

他方, 課題は異なるが予備実験の結果は, 新奇な課 題についての全体的な概念地図作成については, 否定 的な結果を示している。

これらの結果から次のことが推論でき得よう。まず 概念及び概念間の関係について, 少なくとも本実験の ような場合, 最適な作業課題の割合が存在し，それは 実験群 2 の約 $50 \%$ 弱から, 完全完成課題 $(100 \%)$ の間に あるであろうこと, 概念地図の部分完成という作業を 行うことによって概念間の関係を被験者自身が明確化 しているのであろうことである。

ところで, 実験 I -1 から I -3 までの無作図群の 成績に関しては, 実験 I - 2 の無作図群の成績が他の 2 学校のそれよりもよいように見受けられる。そのた め,この実験結果にも共分散分析を用いて処理したが, 学校間の学力差は致し方無いとしても, 実験校の選択 に関しては今後，課題を残したと考えられる。

今回は, 以後の実験に関しては明確に有意差の生じ た実験 I-1 の方法を基本的な方法として採用するこ とにする。

ところで, 実験 I - 1 において効果が生じたのは概 念を記入する事によって被験者が概念間の関係を記憶 し，それが再生されたためではないかという意見もあ
り得る。そこでこの実験における実験群 1 および実験 群 2 について, 各被験者ごとに概念記入作業の正誤と, テスト課題に於いて記入した概念を含む問題と含まな い問題との間に有意差があるか否かを検定したところ, いずれも有意差は見いだせなかった。さらに，結果を 個別に検討すると概念を正確に記入した箇所に相当す るテスト課題に誤答し，まったく別のところに正答す る，という例が見受けられた。

このことは, 空欄に概念を記入する, という行為が 単なる記憶・再生過程ではなく, 被験者の固有の認知 構造に影響を及ぼす過程である事を示唆する。

さて上述のように，作業時間を操作することによっ て実験群の方が無作図群よりも統計的に有意に優れる ことも, またその逆もあり得る。そこで次に，この方 法をもとに作業時間の影響を検討することを試みる。

\section{実 験 II}

\section{目 的}

本実験の目的は, 理科における概念学習において課 題達成に及ほす作業時間の影響を検討することである。 作業時間の検討は，教育的に 2 つの意味を持つ。 1 つは, 教育心理学実験が教育現場に貢献しようとする ならば，まず第 1 に，教育現場において教師や生徒が， 与えられた課題や作業・授業方法に，限定された時間 の中で, 実際にどれだけの時間をかけることが出来る かの検討が必要であることである。 
第 2 に実験における時間配当の問題がある。実験 I の結果採用した方法（部分完成法と名づける）は，あらか じめ概念地図の一部分が出来上がっており，それを完 成させるのが課題である。ところが，概念集団の体制 化の仕方は個人毎に異なっていることは, 先行諸研究 の結果，明らかである。それゆえ，実験者によって概 念地図が部分提示され, その完成を求められる事は, 被験者に葛藤を引き起こすであろう。そのとき，急激 な葛藤処理を強いられた場合, 体制化された構造が一 時的に崩れ, 後の課題遂行に否定的な影響を及ほす恐 れがあることに注意しなければならない。

ここでは後続する研究として「全授業時間に占める 作業時間の割合の，概念関係把握に及ぼす影響」を想 定しているため，作業時間を具体的に設定し，全授業 時間の $10 \%$ (5 分), $30 \%$ (15 分)， $50 \%$ (25 分) の 3 段階 について検討した。

\section{方 法}

実験 II - 1 (作業時間 5 分間)

実験計画 1 要因 2 水準の被験者間計画。共分散分 析法による。統制変数, 基準変数はそれぞれ, 事前テ スト得点, 事後テスト得点である。

\section{実験年月 1993 年 7 月下的。}

被験者 $\mathrm{K}$ 塾夏期講習会参加の中学 3 年生 男子 18 名，女子19名，計 37 名。実験群：男子10名・女子 8 名, 無作図群：男子 8 名・女子11名。これらの群は，K塾 の入会テストの理科の成績に関して, 等質に分けられ ていた。

材料 実験 I と同じ。

- 時間配分 事前テスト 10 分, 作業課題 5 分。干涉課 題 5 分。事後テスト 10 分。合計 30 分 (残りの時間は, 通常 の塾の授業に充てた)。

・実験方法と教示 実験 I - 1 に準ずる。作業課題の み 5 分間。

実験 II - 2 (作業時間 15 分間)

実験計画 1 要因 2 水準の被験者間計画。共分散分 析法による。統制変数, 基準変数はそれぞれ, 事前テ スト得点, 事後テスト得点である。

実験年月 1993年 7 月下旬。

被験者 $\mathrm{K}$ 塾夏期講習会参加の中学 3 年生 男子 18 名, 女子18名, 計 36 名。

材料 実験 I と同じ。

・時間配分 事前テスト10分，作業課題15分。干涉課 題 5 分。事後テスト 10 分。合計 40 分（残りの時間は, 通常 の塾の授業に充てた)。

・実験方法と教示 作業時間が15分間で，他は実験 II
-1 と同じ。

実験 II - 3 (作業時間 25 分間)

実験計画 1 要因 2 水準の被験者間計画。共分散分 析法による。統制変数, 基準変数はそれぞれ, 事前テ スト得点，事後テスト得点である。

実験年月 1993年 7 月下旬。

被験者 $\mathrm{K}$ 塾夏期講習会参加の中学 3 年生 男子 19 名, 女子19名, 計38名。

材料 実験 I と同じ。

・時間配分 事前テスト10分，作業課題25分。干涉課 題 5 分。事後テスト 10 分。合計50分。

・実験方法と教示 作業時間が25分間で, 他は実験 II -1 と同じ。

\section{結 果}

・採点基準 実験 I と同じ。

・評定の信頼性 $\mathrm{K}$ 塾の理科専任教師と筆者とが独立 に採点したところ実験 $\mathrm{II}$ - 1 については $\mathrm{r}=.798, \mathrm{p}$ く.01で有意, 実験 II - 2 については $\mathrm{r}=.724, \mathrm{p}<.01 て ゙$

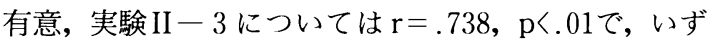
れも有意であった。評定の信頼性は高いといえる。

・実験II-1においては群間に有意差が見いだされた $(\mathrm{F}(1,35)=63.295, \mathrm{p}<.01)$ 。実験群 $($ 無作汹群となった。

実験 IIー2では群間には有意差は見いだされなかった $(\mathrm{F}(1,33)=.096, \mathrm{p}<.01)$ 。実験群=無作図群となった。 実験 II - 3 では群間に有意差が見いだされた $(F(1,35)=$ 44.463, p <.01)。実験群〉無作図群となった（FIGURE 4)。

\section{考 察}

実験 II - 1 においては, 実験群の被験者の多くが, 実験前後で成績が下降した。これは, 概念地図の部分 提示によって引き起こされた葛藤が，5分間では, 解 決・再体制化へと至らなかったことを示すものと思わ れる。この失敗経験によって被験者たちは, 実験前に 解決可能であった問題を解決する事が不可能になって しまったものと考えられる。そこで，この群には残り の時間を再学習に充てた。

このとき，事前テストで高得点を取ったものほど, 有意に大きな成績降下が生じている。これは, 一般に 成績の優れている者ほど知識がより良く構造化されて いると考えられることから, 自己の既有の認知構造と より強い葛藤を生じ, 失敗経験の影響が強く現れたか らであろう。このような負の効果については先行の概 念地図研究では十分に指摘されていなかった。

テスト成績から見れば，作業時間 5 分間 (実験時間の $10 \%$ ) では逆の効果が生じ，15分間 (同 30\%) では効果が ほとんどなく(F值が 0 に近い)，25分間 (同 50\%) の時は 


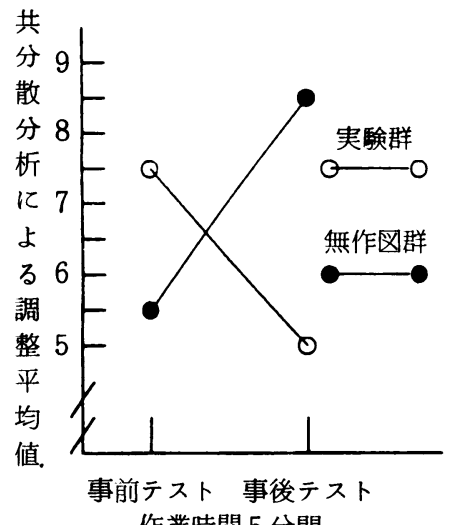

作業時間 5 分間

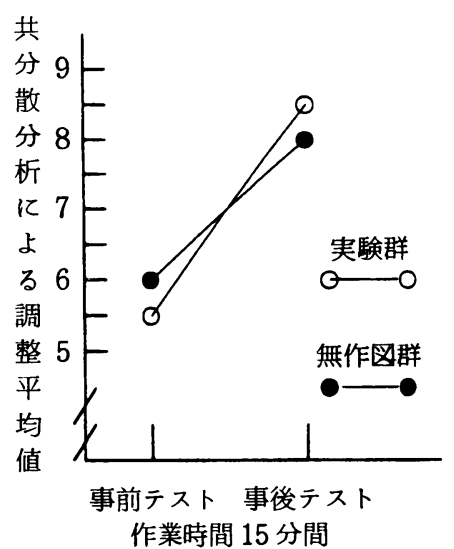

作業時間 15 分間

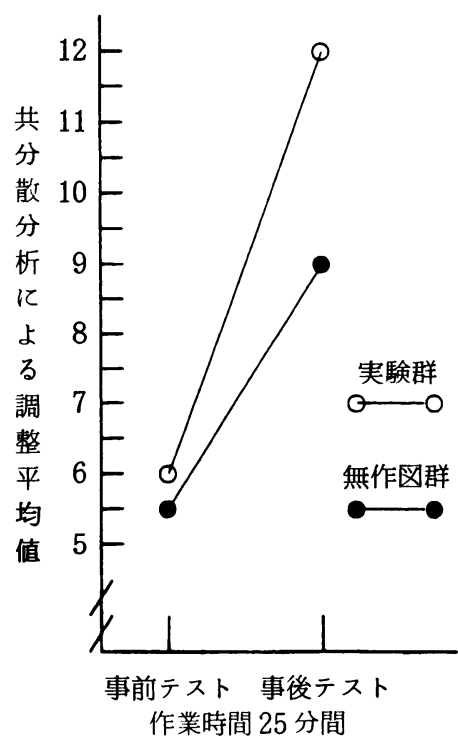

FIGURE 4 作業時間の影響
明確な正の効果が現れている。本研究においては概念 の効果的な教授法に限定しその効果を検討した。その 結果，50分間の実験において，作業時間25分間条件で 通常の概念地図作成法では効果がなく，概念の部分記 入課題においては効果が現れている。

しかしながら, 本研究の最長25分間という時間は, 本研究が本来の概念地図作成法とは異なるとはいえ， 学校などの授業時間の関わりでやむなく設定したもの であり, 実際, Novak 等の主張に比べて余りにも短す ぎ，現実の教育への貢献についても不十分であると言 わざるを得ない。その点において今後に重要な問題を 残したと言え，そこはこれからの課題である。

\section{結論}

認知構造に関する諸研究, とりわけ概念地図作成法 に触発され，概念の部分記入による学習効果を調べる ための実験を行った。

予備実験においては概念地図作成法を実施した。テ スト直前の記憶による影響を取り除くため,「正解」を 見せずに授業時間の $50 \%$ を地図作成に費やしたが，成 績は概念地図を作成しない無作図群を下まわった。

また概念地図完成課題は，概念部分完成方略が最も 良い成績を示し，無作図群の成績を上まわった。この 結果は，この時間内に於いては概念地図の完全完成よ りも部分完成方略の方が，概念間の関係把握により優 れた効果を有する事を示している。言い替えれば地図
作成に於いては概念及び概念間関係の十分な把握が不 可欠である事，また，作業課題に関しては最適の割合 が存在し得るであろう事を示唆している。

本研究においては, 課題数がより多い実験群 2 の成 績がよりよい結果を示した。さらにこの方略を用いて, 概念部分完成に費やす時間の割合を操作したところ, 10\%では負の効果が現れ，50\%費やすことによって， 実験群の成績が概念地図を作成しない群の成績を上ま わった。これらの結果から，概念部分記入課題はテス ト成績からみた限り効果はあるが，授業の中で行うた めには課題に匛じた適切な時間配分が検討される必要 があると言えよう。

本研究は，学校及び塾の 1 時限という限られた時間 内で行われたものであり，各課題にかける時間もその なかで調節した。

しかし，このことはまた本研究の限界を示すもので もある。Novak らの一連の概念地図研究で行われてい るような，充分な思考・討論などの時間が確保されて いるわけではない。そのため, 新しい学習内容を自分 で体系化する能力を育てるという，訓練がなされな かった。

本研究のみに関して言えば，教材単元・従属変数と してのテストの種類・挿入課題の割合・作業時間等を 変化させ, この方略の特質を一層精密に検討して行く ことを今後の研究課題として提起する事は妥当であろ う。 


\section{引用文献}

Ausubel, D.P. 1968 Educational Psychology : A Cognitive View. New York : Holt, Rinehart and Winston.

Champagne, A.B., Klopfer, L.E., Dresna, A.T., \& Squires, D.A. 1981 Structural Representation of Student's Knowledge Before and After Science Instruction. Journal of Research in Science Teaching, 18, No.2, 97-111.

福岡敏行 - 植田千賀子 1992 概念地図作り (CONCEPT MAPPING) の学習効果に対する一考察 一ペーパーテスト法による有効性の確認一 日本 理科教育学会研究紀要, 33, No.2, 1-8.

福岡敏行・笠井 恵 1991 理科学習における概念地 図作り (CONCEPT MAPPING) の有効性に関す る一考察一 6 学年児童の「水溶液の性質」概念の 形成において一 日本理科教育学会研究紀要, 32, No.1, 67-75.

Gagné, E.D. 1985 The Cognitive Psychology of School Learning. Scott Foresman Company, Glenview, Illinois(赤堀 司・岸 学 監訳 1989 学習指導と認知心理学 パーソナルメディア社）

Glynn, S.M., \& Di Vesta, J. 1977 Outline and Hierarchical Organization as Aids for Study and Retrieval. Journal of Educational Psychology, 69, 89-95.

Heinze-Fry, J.A., \& Novak, J.D. 1990 Concept Mapping Brings Long-Term Movement toward Meaningful Learning. Science Education, 74 (4), $461-472$.

Hempel, C.G. 黒崎 博 訳 1967 哲学の世界 7 自然科学の哲学 培風館 P. 156.

広瀬正美 1992 基本的科学概念の構造とは何か 理 科教育学講座 2 東洋館出版社 Pp. 124-142.
家野 等 1992 科学概念の形成と理科教育 理科教 育学講座 2 東洋館出版社 Pp. 223-255. 北尾倫彦 1991 学習指導の心理学 有斐閣 P. 96. Novak, J.D., \& Gowin, D.B. 1984 Learning How to Learn. Cambridge University Press. (福岡敏 行・弓野憲一 訳 1992 子どもが学ぶ新しい学 習法一概念地図法によるメ夕学習一 東洋館出版 社)

Okebukola, P.A. 1990 Attaining Meaningful Learning of Concepts in Genetics and Ecology : An Examination of the Potency of the CONCEPT-MAPPING Technique 1990. Journal of Research in Science Teaching, 27, No.5, 493-504.

Stensvold, M.S., \& Wilson, J.T. 1990 The Interaction of Verbal Ability with Concept Mapping in Learning from a Chemistry Laboratory Activity. Science Education, 74 (4), 473-480.

辰野千寿 1992 教材の心理学 学校図書

付 記

こ0論文は, 1993年度筑波大学大学院博士課程心理 学研究科の中間論文の一部を加筆・訂正してまとめた ものです。

論文の作成にあたり，ご指導をいただきました筑波 大学心理学系教授 (現在, 聖徳大学教授) 福沢周亮先 生に深く感謝いたします。

また, 小野瀬雅人鳴門教育大学助教授, 茂呂雄二筑 波大学心理学系助教授, 及び大学院の方々のご指導に も深く感謝いたします。

宇都宮市立宝木中学校, 宮の原中学校, 雀の宮中学 校, 陽南中学校, 矢板市立片岡中学校の各校の校長先 生はじめ多くの先生がた及び生徒諸君のご協力に感謝 いたします。

(1995.7.19 受稿, ’97.6.11 受理) 